\title{
An In Vitro Assessment of Cytotoxicity of Polyvinyl Siloxane, Polyether, and Polyvinyl Ether Silicone on NIH/3T3 Cells
}

\author{
Priyaranjan $^{1}$, Kunal Kumar ${ }^{2}$, Shruti Keerthi Thota ${ }^{3}$, Ashfaq Yaqoob ${ }^{4}$, Vaibhav Awinashe ${ }^{5}$, Arshad Jamal Sayed ${ }^{6}$
}

\begin{abstract}
Aim and objective: Cytotoxicity of polyvinyl siloxane (PVS), polyether (PE), and polyvinyl ether silicone (PVES) on NIH/3T3 cells. Materials and methods: This in vitro study used elastomeric impression materials which were divided into three groups, group I, II, and III with PVES (EXA'lence light body), PVS (Flexceed light body), and PE impression material (Impregum), respectively. A total of 10 specimens were prepared. Dulbecco's modified Eagle's medium was used for growing mouse cell line NIH/3T3. Cytotoxicity level of all elastomers was measured with the test 3-(4,5-dimethylthiazol-2-yl)-2-5-diphenyltetrazolium bromide assay at regular intervals.

Results: There was a decline in the survival rate with PVES as found on day 1, PVS and PE showed on 3rd and 7th day. Kruskal-Wallis test showed a significant difference in all groups at various days $(p<0.05)$.

Conclusion: Authors found that PVES showed early cytotoxic signs as compared to PVS and PE. Cell viability for PVS was highest as compared to PVES and PE impression materials.

Clinical implication: Cell viability for PVS was highest as compared to PVES and PE impression materials. This information is useful in the selection of impression materials.

Keywords: Polyether, Polyvinyl ether silicone, Polyvinyl siloxane.

The Journal of Contemporary Dental Practice (2020): 10.5005/jp-journals-10024-2927
\end{abstract}

\section{INTRODUCTION}

Elastomeric dental impression materials are widely used material in prosthodontics for recording exact replica of dental tissues (soft and hard). Additional silicone or vinyl polysiloxane (VPS), polysulfide, polyether (PE), and condensation silicones are among commonly used elastomeric impression materials. They are used in recording the impression of removable and fixed implants. ${ }^{1,2}$

Vinyl polysiloxane possess highest accuracy since they are elastic in nature and show increase in dimensional stability. The recently invented polyvinyl ether silicone (PVES) elastomer has unique features as seen with polyvinyl siloxane (PVS) and PE, such as dimensional stability and hydrophilic behavior. ${ }^{3}$

Studies have demonstrated that the use of PE can result in adverse reactions in the body which includes pain, xerostomia, stomatopyrosis, swelling of lips, non-specific cheilitis, dermatitis, and painful and difficult swallowing. These manifestations may be seen within 1-3 days of its use in the oral cavity. ${ }^{4}$

Several studies have been carried out concerning the cytotoxicity of VPS, whereas results have indicated a high degree of toxicity toward cell cultures compared to the negative control. ${ }^{5,6}$ Evaluation of biocompatibility is essential when any medical device is to be used on a patient and cytotoxicity testing using the cell culture technique is the simplest and the easiest form of biocompatibility evaluation that can be used to screen a large number of dental materials. Trapping of elastomeric materials during impression taking into the gingival sulcus for longer duration may result in cytotoxic reactions. For testing these elastomers, numerous arrays and in vitro culturing of cell types are routinely used. ${ }^{7}$ The present study aimed at comparing the cytotoxicity level of different elastomers, such as PVES, PVS, and PE on NIH/3T3 cells (mouse cell line).
${ }^{1}$ Department of Public Health Dentistry, Kalinga Institute of Dental Sciences, KIIT University, Bhubaneswar, Odisha, India

${ }^{2}$ Department of Dentistry, Patna Medical College and Hospital, Patna, Bihar, India

${ }^{3}$ Department of Prosthodontics, Austin, Texas, USA

${ }^{4}$ Department of Prosthodontics, College of Dentistry, King Khalid University, Abha, Kingdom of Saudi Arabia

${ }^{5}$ Department of Prosthodontics, College of Dentistry in Ar Rass Qassim University, Kingdom of Saudi Arabia

${ }^{6}$ Department of Preventive Dentistry, College of Dentistry in Ar Rass Qassim University, Kingdom of Saudi Arabia

Corresponding Author: Kunal Kumar, Department of Dentistry, Patna Medical College and Hospital, Patna, Bihar, India, Phone: +91 9446668892, e-mail: kunalkumar9380@gmail.com

How to cite this article: Priyaranjan, Kumar K, Thota SK, et al. An In Vitro Assessment of Cytotoxicity of Polyvinyl Siloxane, Polyether, and Polyvinyl Ether Silicone on NIH/3T3 Cells. J Contemp Dent Pract 2020;21(11):1262-1265.

Source of support: Nil

Conflict of interest: None

\section{Materials and Methods}

This in vitro study was performed in Department of Dentistry (Prosthodontics), Patna Medical College and Hospital, Patna. This in vitro study was conducted after obtaining approval from institutional ethics committee. Elastomeric impression materials were divided into three groups. Elastomers, such as PVES (EXA'lence light body), PVS (Flexceed light body), and PE impression material (Impregum), were grouped in group I, II, and III, respectively. 
A total of 10 specimens were prepared from each elastomeric material by dispensing and mixing as per the manufacturer's instructions. All these specimens were placed in sterilized brass mold $(1.5 \times 1.5 \mathrm{~cm})$. After polymerization, all were stored in a glass container.

Preparation of specimen was performed according to the International Organization for Standardization standards for cell cytotoxic study. ${ }^{8}$ From the National Centre for Cell Sciences, Pune, mouse fibroblast cell line NIH/3T3 was obtained. Mouse cell line was used in the present study because NIH/3T3 cell line was able to proliferate, adhere, and migrate on the pristine polyaniline films as well as those films doped with sulfamic and phosphotungstic acids; thus, consumption of said forms in biomedicine seems to be hopeful. However, including poly(2-acrylamido-2-methyl1-propanesulfonic) acid modifies the surface characteristics of the polyaniline films and considerably affects the cell behavior. For growing and culturing mouse cell line NIH/3T3, Dulbecco's modified Eagle's medium (DMEM), supplemented with $100 \mu \mathrm{g} / \mathrm{mL}$ streptomycin, 10\% fetal bovine serum (FBS), 2 mM glutamine, and $100 \mathrm{U} / \mathrm{mL}$ of penicillin was utilized. IC50 concentration was assessed for a 3-(4,5-dimethylthiazol-2-yl)-2-5-diphenyltetrazolium bromide (MTT) assay. NIH/3T3 cell line was able to proliferate, adhere, and migrate on the pristine polyaniline films as well as those films doped with sulfamic and phosphotungstic acids; thus, utilization of said forms in biomedicine appears promising. Nevertheless, incorporating poly(2-acrylamido-2-methyl-1-propanesulfonic) acid altered the surface properties of the polyaniline films and significantly affected the cell behavior. ${ }^{9}$

We prepared 30 plates with $\mathrm{NIH} / 3 \mathrm{~T} 3$ cells with various elastomeric materials which were incubated at $37^{\circ} \mathrm{C}$. 3-(4,5-dimethylthiazol-2yl)-2-5-diphenyltetrazolium bromide assay was used for assessing the cytotoxicity level in different groups on 1st day, 3rd day, and 7th day at every 15 minutes, 30 minutes, 60 minutes, and 24 th hour. ${ }^{10}$ The culture medium used without serum to evade the potential interface or inactivation of substances released by testing materials with serum components. ${ }^{11}$

Culture medium containing any soluble extracts of polymerized impression materials was collected after incubation period, in sterile tubes for further evaluation. 3-(4,5-dimethylthiazol-2-yl)-25 -diphenyltetrazolium bromide assay is one of the most regularly used calorimetric assays to evaluate cell viability or cytotoxicity. ${ }^{12}$ This assay establishes mainly cell viability through the evaluation of mitochondrial function of the cells by quantifying the action of mitochondrial enzymes, such as succinate dehydrogenase. ${ }^{13}$

$\mathrm{NIH} / 3 \mathrm{~T} 3$ cells were seeded in a 30-well plate at a density of $5 \times 10^{3}$ cells/well with complete DMEM supplemented with $10 \%$ FBS. After 24 hours, the used medium was removed and the cells were washed with $1 \times$ phosphate-buffered saline (PBS). Cells were exposed to $100 \mu \mathrm{L}$ of extracts for day 1,3 , and 7 , with the time interval of 15 minutes, 30 minutes, 60 minutes, and 24th hour; the time interval is used to differentiate the level of survival percentage of cells and cytotoxic virulence between each time interval. The same time interval is followed for day 3 and 7. Fifty microliters of MTT ( $5 \mathrm{mg} / \mathrm{mL}$ in PBS) were added to each well. Subsequently, the plates were incubated at $37^{\circ} \mathrm{C}$ for 3 hours at $5 \% \mathrm{CO}_{2} \cdot{ }^{12,14}$

At end of the incubation, excess MTT solution was removed and the formazan crystals were dissolved with $100 \mu \mathrm{L}$ of dimethyl sulfoxide. ${ }^{14,15}$

Results were expressed as mean and standard deviation (SD) after entering it in MS excel sheet. Results were compared using analysis of variance (ANOVA) test and Kruskal-Wallis and cell viability on 1st day, 3rd day, and 7th day was recorded. The level of significance was labeled below 0.05 .

\section{Results}

Table 1 indicates distribution of different elastomeric impression materials in various groups. Table 2 shows cell viability recorded on day 1 at 15 minutes was 58, 157, and 155 in group I, II, and III, respectively. It was 76,124 , and 148 at 30 minutes in group I, II, and III, respectively. It was 6,134 , and 136 at 60 minutes in group I, II, and III, respectively. At 24 hours, it was 26, 80, and 136 in group I, II, and III, respectively.

Table 3 shows cell viability recorded on day 3 at 15 minutes was 36,82 , and 104 in group I, II, and III, respectively. It was 28,72 , and 114 at 30 minutes in group I, II, and III, respectively. It was 24,82 , and 112 at 60 minutes in group I, II, and III, respectively. At 24 hours, it was 28,81 , and 114 in group I, II, and III, respectively. Figure 1 shows cell viability recorded on day 7 at 15 minutes was 19, 21, and 85 in group I, II, and III, respectively. It was 20,13 , and 78 at 30 minutes

Table 1: Distribution of elastomers used in the study

\begin{tabular}{llll}
\hline Groups & Group I & Group II & Group III \\
\hline Material & $\begin{array}{l}\text { Polyvinyl ether } \\
\text { silicone (PVES) }\end{array}$ & $\begin{array}{l}\text { Polyvinyl silox- } \\
\text { ane (PVS) }\end{array}$ & Polyether (PE) \\
\hline
\end{tabular}

Table 2: Assessment of cell viability of NIH 3T3 cells in different groups on day 1

\begin{tabular}{lllll}
\hline Time period & 15 minutes & 30 minutes & 60 minutes & 24 hours \\
\hline Group I & 58 & 76 & 68 & 26 \\
Group II & 157 & 124 & 134 & 80 \\
Group III & 155 & 148 & 136 & 136 \\
\hline
\end{tabular}

Table 3: Assessment of cell viability of NIH 3T3 cells in different groups on day 3

\begin{tabular}{lllll}
\hline Time period & 15 minutes & 30 minutes & 60 minutes & 24 hours \\
\hline Group I & 36 & 28 & 24 & 28 \\
Group II & 82 & 72 & 82 & 81 \\
Group III & 104 & 114 & 112 & 114 \\
\hline
\end{tabular}

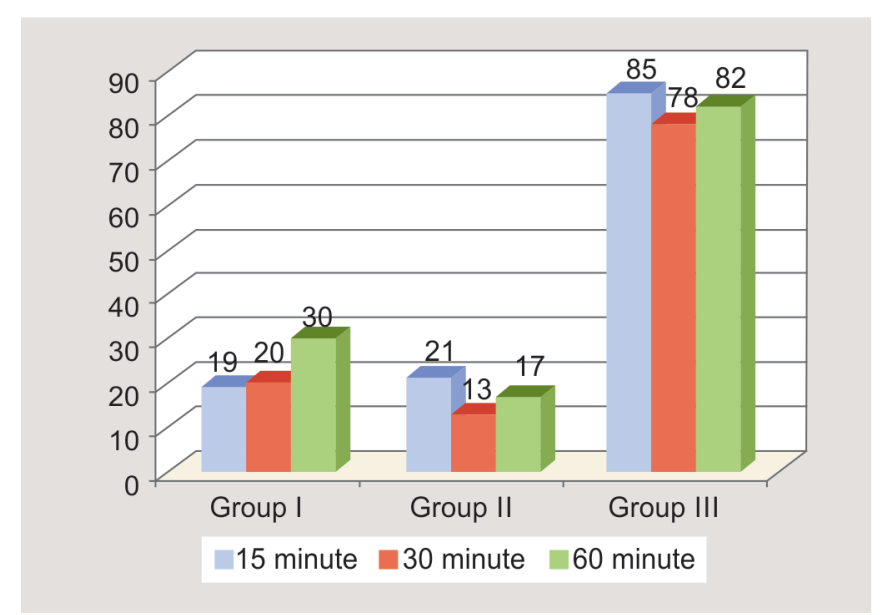

Fig. 1: Assessment of cell viability of NIH 3 T3 cells in different groups on day 7 
Cytotoxicity of Elastomeric Dental Impression Materials on NIH/3T3 Cells

Table 4: Mean survival rate in all groups

\begin{tabular}{llll}
\hline Time period & Day 1 & Day 3 & Day 7 \\
\hline Group I & $25.1 \pm 8.14$ & $23.6 \pm 7.06$ & $24.6 \pm 6.12$ \\
Group II & $106.8 \pm 32.6$ & $66.4 \pm 34.5$ & $18.2 \pm 32.8$ \\
Group III & $120.6 \pm 16.5$ & $94.2 \pm 14.7$ & $74.6 \pm 16.1$ \\
$p$ value & 0.001 & 0.001 & 0.001 \\
\hline
\end{tabular}

Kruskal-Wallis test, $p<0.05$, significant

Table 5: Period effect within the subject

\begin{tabular}{llllll}
\hline Groups & Sum of squares & Df & Mean square & $F$ & $p$ value \\
\hline Group I & 24.86 & 1.82 & 12.84 & 0.32 & 0.81 \\
Group II & $16,242.6$ & 1.04 & $15,614.2$ & 11.72 & 0.02 \\
Group III & $4,612.8$ & 1.28 & $3,640.2$ & 25.76 & 0.01 \\
\hline
\end{tabular}

in group I, II, and III, respectively. It was 30, 17, and 82 at 60 minutes in group I, II, and III, respectively. At 24 hours, it was 29, 19, and 64 in group I, II, and III respectively.

Table 4 shows that mean \pm SD cell viability survival of cells at day 1 in group I was $25.1 \pm 8.14,106.8 \pm 32.6$ in group II, and 120.6 \pm 16.5 in group III. On day 3 , it was $23.6 \pm 7.06,66.4 \pm 34.5$, and $94.2 \pm 14.7$ in group I, II, and III, respectively. It was $24.6 \pm 6.12,18.2$ \pm 32.8 , and $74.6 \pm 16.1$ on day 7 in group I, II, and III, respectively. Kruskal-Wallis test showed a significant difference in all groups at various days. Table 5 shows test of within-subject effect over time in each group.

\section{Discussion}

The biocompatibility of elastomers may be evaluated by determining the cytotoxicity level. The utility of these tests for diagnosing the cytotoxicity of dental materials is well established. ${ }^{16}$ The potential cytotoxicity of elastomeric materials may be tested by direct and indirect tests. In direct test, the cells are introduced into the material and in indirect test the cells are inserted to the eluted extracts of the impression materials. ${ }^{17}$ Test, such as dye exclusion methods, can be used for measuring the cell viability. However, it has its limitations. 3-(4,5-dimethylthiazol-2-yl)-2-5diphenyltetrazolium bromide is a calorimetric assay used frequently in evaluating the cytotoxicity or cell viability. ${ }^{12}$ The cell viability is assessed principally through the evaluation of mitochondrial function of the cells by calculating the succinate dehydrogenase which is a potent mitochondrial enzyme. ${ }^{13}$ This method is safe and easily employed. It has high reproducible capacity which helps in assessing the cytotoxicity and cell viability. ${ }^{18}$ The present in vitro study compared the cytotoxicity level of various elastomers included in research.

In the present study, we used elastomeric impression materials, such as PVES, PVS, and PE impression materials which were grouped into group I, group II, and group III, respectively.

We observed that cell viability recorded on day 1 at 15 minutes was 58 in group I, 157 in group II, and 155 in group III. At 30 minutes, it was 76,124 , and 148 in group I, II, and III, respectively. We found cell viability of 6, 134, and 136 in group I, II, and III, respectively, recorded at 60 minutes. At 24 hours, it was 26, 80, and 136 in group I, II, and III, respectively. Similarly, cell viability was measured on day 3 and 7 at 15 minutes, 30 minutes, 60 minutes, and 24 hours. Rajasimhan et al. $^{14}$ in their in vitro study compared the cytotoxicity of PVES, PVS, and PE elastomeric impression materials using 24 specimens.
Result demonstrated that on 1st day group I had decrease in the survival rate on day 1 and group II and III on day 3rd and 7th which were statistically significant $(p<0.001)$.

We found a significant difference in mean \pm SD cell viability survival of cells. At day 1 in group I, it was $25.1 \pm 8.14,106.8 \pm 32.6$ in group II, and $120.6 \pm 16.5$ in group III. On day 3 , it was $23.6 \pm 7.06$, $66.4 \pm 34.5$, and $94.2 \pm 14.7$ in group I, II, and III, respectively. On day 7 , group I had $24.6 \pm 6.12$, group II had $18.2 \pm 32.8$, and group III had 74.6 \pm 16.1. Roberta et al. ${ }^{11}$ determined the cytotoxicity of PEs and VPSs impression materials using indirect tests which showed that MTT test, cell counting, and light microscopy were effective in determining the cellular viability of extracts of PE materials which showed reduction. The direct tests showed reduction in cellular proliferation of PEs which was unaffected by the presence of VPSs.

In this study, we observed that there was no change in cell viability from day $1-7$ in group I ( $p>0.05)$, but PE and PVS were statistically significant $(p<0.05)$. We found highest cell viability in group II. Boraldi et al. ${ }^{19}$ compared various elastomeric materials with Balb/c 3T3 and human gingival fibroblasts. It was evident from the study that there was a clear decline in the cellular viability of $\mathrm{Balb} / \mathrm{c}$ 3T3 tests resulted from express light body. Most cytotoxic material was PE. Primary cell line found to be less sensitive to the toxic effect as compared to permanent cell line.

Augustine et al. evaluated the antiproliferative action of earthworm coelomic fluid (ECF) on oral cancer cell line squamous cell carcinoma (SCC)-9, and concluded that antiproliferative activity of ECF has antiproliferative effect on oral cancer cells. ${ }^{20}$ Augustine et al. in a systematic review included 23 studies for analysis with 18 in vitro studies and 4 of combined in vitro and in vivo methods. They stated that, in wound healing, earthworm extracts have been used successfully as an antimicrobial and antiinflammatory agent. They have antitumor activity and earthworm extracts showed satisfactory anticancer effect on several types of cancers. ${ }^{21}$ Augustine et al. analyzed the dose- and time-dependent antiproliferative effect of ECF of Eisenia fetida (EF), Eudrilus eugeniae (EE), and Perionyx excavatus (PE) on oral cancer cell line KB 3-1. They concluded that on in vitro evaluation, ECF of EE has a promising antiproliferative effect in a dose- and time-dependent method on oral squamous carcinoma KB 3-1 cells. ${ }^{22}$

The shortcoming of the present study is that cytotoxicity of elastomeric materials was checked with indirect test only. Humanbased cell lines were not used in this study. Further studies are required to evaluate the cytotoxic effect on direct and in vivo method. 


\section{CONCLUSION}

It was evident in the study that PVES had early cytotoxic signs as compared to PVS and PE. Cell viability for PVS was highest as compared to other impression materials.

\section{References}

1. Eames WB, Wallace SW, Suway NB, et al. Accuracy and dimensional stability of elastomeric impression materials. J Prosthet Dent 1979;42(2):159-162. DOI: 10.1016/0022-3913(79)90166-5.

2. Ciesco JN, Malone WF, Sandrik JL, et al. Comparison of elastomeric impression materials used in fixed prosthodontics. J Prosthet Dent 1981;45(1):89-94. DOI: 10.1016/0022-3913(81)90018-4.

3. Blankenau RJ, Kelsey WP, Cavel WT. A possible allergic response to polyether impression material: a case report. J Am Dent Assoc 1984;108(4):609-610. DOI: 10.14219/jada.archive.1984.0357.

4. Rafael CF, Liebermann A. Clinical characteristics of an allergic reaction to a polyether dental impression material. J Prosthet Dent 2017;117(4):470-472. DOI: 10.1016/j.prosdent.2016.08.031.

5. Kwon JS, Lee SB, Kim KM, et al. Positive control for cytotoxicity evaluation of dental vinyl polysiloxane impression materials using sodium lauryl sulfate. Acta Odontol Scand 2014;72(8):618-622. DOI: 10.3109/00016357.2013.879996.

6. Sydiskis RJ, Gerhardt DE. Cytotoxicity of impression materials. J Prosthet Dent 1993;69(4):431-435. DOI: 10.1016/0022-3913(93)90193R.

7. Mittermüller $\mathrm{P}$, Szeimies RM, Landthaler $\mathrm{M}$, et al. A rareallergy to a polyether dental impression material. Clin Oral Investig 2012;16(4):1111-1116. DOI: 10.1007/s00784-011-0618-8.

8. Wenzelewski DIK, Tinkler J, Cook P, et al., Biological and clinical evaluation of medical devices. https://www.iso.org/committee/54508. html. [Last cited on 2020 July 24].

9. Rejmontová P, Capáková Z, Mikušová N, et al. Adhesion, proliferation and migration of NIH/3T3 cells on modified polyaniline surfaces. Int J Mol Sci 2016;17(9):1439. DOI: 10.3390/ijms17091439.

10. Sakaguchi R, Powers J. Craigs Restorative Dental Materials. 13th ed., St. Louis: Elsevier; 2012.

11. Roberta T, Federico M, Federica B, et al. Study of the potential cytotoxicity of dental impression materials. Toxicol In Vitro 2003;17(56):657-662. DOI: 10.1016/S0887-2333(03)00107-3.
12. Mosmann T. Rapid colorimetric assay for cellular growth and survival: application to proliferation and cytotoxicity assays. J Immunol Methods 1983;65(1-2):55-63. DOI: 10.1016/0022-1759(83)90303-4.

13. Stone V, Johnston $H$, Schins RP. Development of in vitro systems for nanotoxicology: methodological considerations. Crit Rev Toxicol 2009;39(7):613-626. DOI: 10.1080/10408440903120975.

14. Rajasimhan NV, Jayaraman S, Ali DJ, et al. Evaluation of cytotoxicity levels of poly vinyl ether silicone, polyether, and poly vinyl siloxane impression materials: an in vitro study. J Indian Prosthodont Soc 2019;19(4):332-337. DOI: 10.4103/jips.jips_261_19.

15. Jeng HW, Feigal RJ, Messer HH. Comparison of the cytotoxicity of formocresol, formaldehyde, cresol, and glutaraldehyde using human pulp fibroblast cultures. Pediatr Dent 1987;9(4):295-300.

16. Nassar U, Oko A, Adeeb S, et al. An in vitro study on the dimensional stability of a vinyl polyether silicone impression material over a prolonged storage period. J Prosthet Dent 2013;109(3):172-178. DOI: 10.1016/S0022-3913(13)60038-4.

17. Chen SY, Chen CC, Kuo HW. Cytotoxicity of dental impression materials. Bull Environ Contam Toxicol 2002;69(3):350-355. DOI: 10.1007/s00128-002-0069-7.

18. Aslanturk OS, Askın Celik T, Karabey B, et al. Active phytochemical detecting, antioxidant, cytotoxic, apoptotic activities of ethyl acetate and methanol extracts of Gallium aparine L. Br J Pharma Res 2017;15(6):1-16.

19. Boraldi F, Coppi C, Bortolini S, et al. Cytotoxic evaluation of elastomeric dental impression materials on a permanent mouse cell line and on a primary human gingival fibroblast culture. Materials 2009;2(3):934944.

20. Augustine D, Rao RS, Anbu J, et al. In vitro antiproliferative effect of earthworm coelomic fluid of Eudrilus eugeniae, Eisenia foetida, and Perionyx excavatus on squamous cell carcinoma-9 cell line: a pilot study. Phcog Res 2017;9(Suppl 1):61-66. DOI: 10.4103/pr. pr_52_17.

21. Augustine D, Rao RS, Anbu J, et al. Anticancer prospects of earthworm extracts: a systematic review of in vitro and in vivo studies. Phcog Rev 2018;12(23):46-55. DOI: 10.4103/phrev.phrev_45_17.

22. Augustine $D$, Rao RS, Jayaraman $A$, et al. Anti-proliferative activity of earthworm coelomic fluid using oral squamous carcinoma KB 3-1 cells: an in vitro study with serine protease analysis. Phcog Mag 2018;14(59):528-534. DOI: 10.4103/pm.pm_412_18. 